\title{
LEADERSHIP, VISION, \& REFLECTION APPLYING IGNATIAN CONCEPTS TO DEVELOP TRANSFORMATIONAL LEADERS WITH A SELECT APPLICATION TO SUSTAINABILITY
}

\author{
DAVID W. ARNESEN \\ Albers School of Business and Economics \\ Seattle University \\ Seattle, Washington, U.S.A. \\ arnesen@seattleu.edu
}

ABSTRACT. Jesuit business schools have an obligation to develop ethical transformational leaders who seek a just and humane world. Whether it is addressing the needs of social justice or leading change to advance sustainability, these institutions have a unique ability to apply Ignatian concepts in developing responsible leaders. This article examines these concepts, including the insight of reflection, the gift from empowering others, the strength from building trust, and the rewards of silent servant leadership to help others rise.

In examining the "modeling" of successful leaders, we will look at how the transparency of leadership is essential to lead change in areas such as social justice and sustainability. We will consider, for example, how Jesuitvalued education can fill the void of effective environmental leadership with regard to sustainability. We will establish the case that Jesuit schools are in a unique position to develop these leadership skills to facilitate this necessary environmental dialogue. Thus, in reflecting on the philosophy of developing

CITATION OF THIS ARTICLE IN PRESS: Arnesen, D. W. 2018. Leadership, Vision, \& Reflection: Applying Ignatian Concepts to Develop Transformational Leaders with a Select Application to Sustainability. Journal of Management for Global Sustainability 6(2). 
leadership, we will see how Ignatian principles can form the core foundation for building great leaders.

Finally, this article looks to the future of Jesuit business school education. What are the changes necessary in teaching leadership to advance social justice and lead sustainability change? What reflection on Ignatian concepts must faculty and administration pursue so that Jesuit business schools are at the forefront of leadership? We will conclude the "modeling" of leaders with how our institutions can foster principled leadership within every student through the application of Ignatian concepts.

KEYWORDS: leadership; sustainability; Ignatian; reflection; discernment

\section{INTRODUCTION}

In his encyclical letter on the environment entitled "On Care for Our Common Home," Pope Francis states that "we lack leadership capable of striking out on new paths and meeting the needs of the present with concern for all and without prejudice towards coming generations" (Francis, 2015). He also addresses in the same document the issues of air and water pollution, climate change, loss of biodiversity, and the need for functioning ecosystems. Most importantly, however, he calls for dialogue among all peoples:

I urgently appeal, then, for a new dialogue about how we are shaping the future of our planet. We need a conversation which includes everyone, since the environmental challenge we are undergoing, and its human roots, concern and affect us all. (Francis, 2015)

This obligation to care for the planet is not new-it can be traced back in Scripture to the books of Genesis and Psalms. Nor is it new within the church; as Pope Paul VI stated, "Due to an ill-considered exploitation of nature, humanity runs the risk of destroying it and becoming in turn a victim of this degradation" (Paul VI, 1971). Pope Emeritus Benedict XVI also extolled the extent of this obligation, "We are all responsible for the protection and care of the environment. This responsibility knows no boundaries" (Benedict XVI, 2010).

That care for the environment is a moral issue is perhaps most important (Martin, 2017). As such, it must be part of the conversation in leadership development within every Jesuit business school. Ignatian principles are keys to this development. Discernment, for example, one of the Ignatian principles examined herein, shows how applying 
this principle helps guide leaders in making carefully considered and informed decisions. These Ignatian concepts, therefore, should be the foundation of every Jesuit business school.

The skills necessary for leadership can clearly be learned through education and experience (Mumford, Marks, Connelly, Zaccaro, \& ReiterPalmon, 2000). Transformational leaders, in addition, need the ability to embrace change. Such leaders, it should be noted, possess the following four characteristics: "idealized influence, inspirational motivation, intellectual stimulation, and individualized consideration" (Avolio, Waldman, \& Yammarino, 1991). We will thus show in the following how Jesuit business education can develop both the skills and characteristics necessary for transformational leadership.

\section{THE FORMATION OF AN IGNATIAN BUSINESS LEADER}

In developing Ignatian business leaders, we must first listen to and reflect on what students within Jesuit business schools need to develop their full Ignatian leadership potential. What do students in the $21^{\text {st }}$ century require to become ethical servant leaders? Is there a certain void which Jesuit business schools have the unique opportunity to fill? To develop leadership, we first have to listen and reflect:

Be slow to speak, and only after having first listened quietly, so that you may understand the meaning, leanings, and wishes of those who do speak. Thus you will better know when to speak and when to be silent. (Ignatius of Loyola, 1546)

Ignatius thus set forth the first foundation for developing leadership within Jesuit education - the need to listen. While we as educators within Jesuit business schools can express leadership values and concepts using our words, we must first listen so as to construct our dialogue to have the greatest impact.

Silence is the foundation for this "effective listening" which must include reflection and discernment. Excellent examples of this as practiced in Jesuit higher education are the Ignatian silent retreats where our students have the opportunity to explore their own leadership qualities through reflection and discernment. Silence is also a key part of the examen "exercise" of reflecting on the day, embracing the spirit, looking for what tomorrow will bring, and discerning what one will need to lead others with Ignatian values. 
The Ignatian principles of humility and discernment also enhance dialogue with our students (Byron, 2011). If we engage our students with humility, we can expand their own reflection and discernment as they seek to discover what transformational values are necessary for effective leadership.

\section{TRANSFORMATIONAL IGNATIAN VALUES}

Ignatian leadership requires transformational values. Ignatian values raise the very questions that leaders trained in Jesuit business schools must ask, questions that require reflection on the following concepts:

1. the concept of empowering others;

2. the power that comes from reflection;

3 . the energy of us rather than me;

4. how vision builds leadership;

5. the obligation to build trust;

6. how transparency builds leadership;

7. how transparency strengthens authenticity;

8. how leadership can bring differences together;

9. putting business into "life's" perspective;

10. believing in others;

11. being a silent leader;

12. teaching the ability to do the impossible;

13. knowing how our actions impact others;

14. how we are more alike than different; and

15. the development of servant leadership.

Studies have clearly shown that reflection builds quality leadership (Callahan, 2013). Developing Ignatian leadership, therefore, requires reflection on values. It brings forth the principles of developing the whole person, creating social justice, and moving others to do the right thing. Indeed, reflection on the transformational concepts outlined above creates ethical leadership and helps develop moral values. Jesuit business schools, therefore, must develop more than just transactional business managers; they must develop transformational leaders who will lead at every level of an organization and who are committed to doing the right thing. As the famous management educator Peter F. Drucker stated, "Management is doing things right; leadership is doing the right things" (Drucker, 2001). Clearly, transformational values developed within the Ignatian framework of reflection can lead Jesuit business students to do the right thing. 
Reflection also leads us to change, and change is essential for individuals, business, and society to progress and move forward. As President Harry S. Truman stated, "Men make history and not the other way around. In periods where there is no leadership, society stands still. Progress occurs when courageous, skillful leaders seize the opportunity to change things for the better." Reflection developed in the Ignatian framework allows us to examine what has happened from various perspectives and then pursue effective change through discernment (Mauri, Neiva de Figueiredo, \& Rashford, 2015). If we as educators embrace the Ignatian ideals to empower and lift others up, we will develop leaders who embrace effective change not just in business but in all of society. Indeed, the key to "modeling" those Ignatian values is to become the servant leader.

\section{AN EXAMINATION OF EMPOWERING OTHERS: THE SERVANT LEADER}

It is clear that empowerment in business leads to better performance (Garton, 2017). A foundation of Jesuit education, the servant leader is committed to empowering others. This empowerment of others is a key to business leadership. As Jack Welch, former chairman and CEO of General Electric, stated, "Before you are a leader, success is all about growing yourself. When you become a leader, success is all about growing others." Now the growth of others is clearly part of our Ignatian commitment, one that goes beyond business. It is a commitment to all of society, particularly with a special obligation to the poor and marginalized so as to lift them up. If we apply this philosophy to Jesuit business education, we become educators that develop leaders who will empower others to rise. As Microsoft cofounder Bill Gates said regarding future leaders, "As we look in the next century, leaders will be those who empower others."

What unique characteristics must Jesuit business education embrace in developing the servant leader? First, there has to be a focus on the Ignatian practice of humility. As business leader and philanthropist Andrew Carnegie noted, "No man will make a great leader who wants to do it all himself, or to get all the credit for doing it." Humility gives credit to others. Transformational business leadership, therefore, needs the element of humility to embrace fully the significance of lifting others rather than self.

Second, a servant leader must be transparent to empower others. True transparency in the business context, where information is available 
and flows freely within an organization, is often not the case. There are many reasons for lack of transparency, yet we do know that "An organization's capacity to compete, solve problems, innovate, meet challenges, and achieve goals-its intelligence, if you will-varies to the degree that information flow remains healthy" (Bennis, Goleman, O'Toole, \& Biederman, 2008). Likewise, there must be transparency for servant leaders to empower others to compete, solve problems, innovate and meet challenges.

Third, transparency requires trust and authenticity. Jesuit business education must "model" examples of trust building by leading through example, open communications, and care for the whole person. Trust building only works if there is authenticity and a true commitment to others. Perhaps such belief in others can be summed up best by the famous North Carolina State basketball coach Jim Valvano, who said, "My father gave me the greatest gift anyone could give another person; he believed in me." This gift to believe in others goes to the very heart of Ignatian values. If we "model" that respect within our Jesuit business schools, creating a belief in others, we will develop students who as leaders not only transform business but also leaders who transform those they interact with to also become servant leaders.

\section{TRANSFORMATION TO ACHIEVE THE IMPOSSIBLE}

Saint Francis of Assisi said, "Start by doing what's necessary; then do what's possible; and suddenly you are doing the impossible." We can build upon many foundations within Ignatian teachings to help our students achieve what may seem impossible. First and foremost is the development of the whole person within the Jesuit business school context, which is essential. Unlocking an individual's full leadership potential clearly cannot be achieved without the development of the whole person. Jesuit business school education, therefore, the development of the whole person, mind, body, and spirit, has the unique ability to unlock this potential.

Second, the Jesuit value of cura personalis, care for the person, can unlock this potential even further. This focus on the individual is established through our expression of humility, transparency, and trust. If we truly follow cura personalis, we will inspire our business students to act not solely on transactional elements, but rather to consider their actions in the context of being a transformational leader.

Third, the Jesuit principle ad majorem Dei gloriam ("for the greater glory of God") can be found in the Ignatian practice of magis. Pope 
Francis, in fact, notes the importance of spirituality in motivating us to solve the issues of ecological stewardship:

Here, I would like to offer Christians a few suggestions for an ecological spirituality grounded in the convictions of our faith, since the teachings of the Gospel have direct consequences for our way of thinking, feeling and living. More than in ideas or concepts as such, I am interested in how such a spirituality can motivate us to a more passionate concern for the protection of our world. (Francis, 2015)

Jesuit education helps build this spirituality through magis, often a part of St. Ignatius's spiritual exercises which include reflection and contemplation of what has occurred and how to improve. It builds selfawareness, ingenuity, heroism, and a drive to accomplish goals (Lowney, 2003). Magis within Jesuit business teaching can build a personal commitment to act, aim high, achieve excellence, and serve others. It is but another example of Jesuit education with which we can help our students achieve what seems to be the impossible.

It should be noted that self-awareness is one of the key elements in developing emotional intelligence. Emotional intelligence, the ability to understand your own emotions and those of others, empathy, and how others will react to you, is a key skill of effective leadership (Ovans, 2015).

Combining the elements of development of the whole person, cura personalis, and magis makes servant leaders grow with the courage to be transformational. As Michelle Obama noted, "You may not always have a comfortable life and you will not always be able to solve all of the world's problems at once but don't ever underestimate the importance you can have because history has shown us that courage can be contagious and hope can take on a life of its own." Developing this servant leader courage is thus essential if we are to address important social justice issues such as sustainability.

\section{IGNATIAN-BASED SOCIAL JUSTICE INVOLVES SUSTAINABILITY}

Part of our Jesuit business school commitment to social justice must include a concern for sustainability (Obermiller \& Atwood, 2014). Sustainability looks at how we impact the earth, air, and water for future generations. It looks to balance environmental protection with economic development and social equity (Curran, 2014). If we truly believe in a commitment to improve social justice, this must include improving sustainability for future generations. 
Let us first examine what sustainability leadership is. The Center for Ethical Leadership found that leaders go through a "five stage pattern of sustainability leadership" which engages the following elements: awareness, experimentation, systems thinking, resource commitment, and sharing. First, there is an acknowledgement of the issues along with a will to move forward based on values. Second, the element of experimentation then looks at initiating a specific sustainability project. Third, systems thinking considers the broad impact of the sustainability initiative. Fourth, resource commitment recognizes the need to allocate resources to achieve sustainability. Finally, sharing aims at being a sustainability advocate within the industry (Center for Ethical Leadership, 2005). The Center also noted characteristics shared among the leaders who participated in the study: passion, vision, a "participatory organizational culture," and a "willingness to learn."

Applying Ignatian concepts gives us a unique ability in Jesuit business education to address these characteristics of sustainability leadership. As Rockhurst University president Thomas Curran, S.J., pointed out in 2014, "Ignatian spirituality speaks of 'our way of proceeding' and considers all engagements as conversations. The pursuit of sustainability requires thoughtful and patient engagement. Providing that conversation the time it needs demands a discipline and intentionality" (Curran, 2014).

Considering the diversity of opinions on how best to address sustainability, it can be argued that Ignatian philosophy possibly provides a unique "leadership" way of bringing divergent ideas together. First, Ignatian-based leadership looks at gaining engagement not through criticism but through conversations. It recognizes the complexity of the issues. How do we balance, for example, the current economic needs of developing countries that use resources in a less sustainable manner with the worldwide goal of greater sustainability and resource protection for future generations? Applying Ignatian teachings which recognize the need for in-depth and "patient" engagement can help in examining complex sustainability questions such as this.

While progress has been made toward achieving greater sustainability, much more clearly needs to be done as the world is still depleting and significantly polluting many resources which must be protected for future generations. Solutions to sustainability issues will require leaders with more than just "technical managerial skills." Given, therefore, that all business schools teach such skills, the unique ability of Jesuit business schools to teach transformational leadership is perhaps what is necessary for moving solutions forward to solve the complex issues of sustainability. 
There is another element of Jesuit education that can lead us to more sustainable solutions. One of the benefits of developing the whole person is that doing so can foster "imagination" within the student and lead to "heightened creativity and empowerment" (Imanaka, 2016). This "imagination" and "creativity" may arguably be exactly what is needed to provide new solutions for achieving greater sustainability in the future. Pope Francis noted the need for these new avenues of thought to address sustainability, particularly in business:

If we look at the larger picture, we can see that more diversified and innovative forms of production which impact less on the environment can prove very profitable. It is a matter of openness to different possibilities which do not involve stifling human creativity and its ideals of progress, but rather directing that energy along new channels. (Francis, 2015)

Finally, sustainability in the next century needs to be addressed from a global perspective. As Pope Francis noted,

An interdependent world not only makes us more conscious of the negative effects of certain lifestyles and models of production and consumption which affect us all; more importantly, it motivates us to ensure that solutions are proposed from a global perspective, and not simply to defend the interests of a few countries. (Francis, 2015)

Jesuit education has the unique ability to address sustainability worldwide-there are 28 Jesuit business schools in the United States and 55 international members of the IAJBS. If we're committed to developing transformational leaders who are committed to social justice, then that needs to include business education focused on creating a global impact on improving sustainability.

\section{EXAMPLES OF TRANSFORMATIONAL LEADERS}

It can be argued that the influence, the "leadership," of Jesuiteducated individuals in virtually every profession has been significant. We need to look only at a few among the thousands of examples to establish impact. In politics, Jesuit-educated leaders from Thomas P. "Tip" O'Neil to John Boehner have reached across the entire political spectrum. Jesuit school alumni include Jerry Brown, Andrew Cuomo, Geraldine Ferraro, Thomas Foley, Tim Kaine, John Kerry, Patrick Leahy, Barbara Mikulski, Janet Napolitano, and Leon Panetta. This influence, this "leadership," extends globally as well to include Vicente Fox (former 
President of Mexico), Gloria Macapagal-Arroyo and Benigno Aquino III (former Presidents of the Philippines), Park Geun-hye (former President of Korea), Pierre Elliott Trudeau (former Prime Minister of Canada), Ramaswamy Venkataraman (former President of India), Frederick Weld (former Prime Minister of New Zealand), Alejandro Toledo Manrique (former President of Peru), and Saad Hariri (Prime Minister of Lebanon).

This Jesuit-educated "leadership" influence also goes well beyond politics. Representatives in entertainment and the media have included Bing Crosby, Denzel Washington, Alfred Hitchcock, Bob Newhart, Charles Osgood, Chris Mathews, Bill Murray, Tim Russert, and Salma Hayek. William F. Buckley, Jr., Tom Clancy, Jr., and Sir Arthur Conan Doyle are counted among those leaders in literature who were educated in Jesuit universities. In sports, Jesuit-educated leaders include Vince Lombardi, Bill Russell, Bob Cousy, Pete Rozelle, and Don Shula.

Finally, Jesuit-educated leaders in business have included John Paul Getty (founder of Getty Oil Company), Peter Lynch (Manager of the Fidelity Magellan Fund from 1977-1990), Joseph Berardino (former CEO of Arthur Anderson), Sabeer Bhatia (co-founder of Hotmail), Timothy Donahue (Executive Chairman of Sprint Nextel), Charles F. Dolan (founder of Cablevision), Maria Elena Lagomasino (CEO of JP Morgan Private Bank from 2001-2005), John Leahy (COO of Airbus), Mark Thompson (Director-General of the BBC), and Jim Whittaker (mountaineer, environmentalist, and former CEO of Recreational Equipment, Inc.).

Clearly, if Jesuit education can help develop leaders across these professions, it certainly can develop those who will address sustainability.

\section{PRINCIPLED LEADERSHIP AND IGNATIAN TEACHING}

As Dov Seidman pointed out in the World Economic Forum, "Leaders need to act with conviction founded on core values, because only principled, ethical leadership will survive the challenges ahead." He noted six key principles of that leadership: ethics, the ability to stop and think, extend trust, embrace two way communications, demonstrate moral authority, and lead with a purpose (Seidman, 2015). Each one of these elements of leadership are within the core of a Jesuit business education.

Teaching ethics, first and foremost, is the core of every Jesuit university, and there is no doubt that ethics and moral standards are essential for effective leadership (Giles, 2016). Second, Seidman's element 
of "stop and think" is found in Ignatian teaching as the element of reflection, which is important not only for leadership but also for learning. It is one of the key elements of a Jesuit business education. Indeed, studies have shown that greater learning occurs when there is reflection and that actual experience adds to the learning when it is viewed through the reflective observations to "synthesize, abstract, and articulate" (Di Stefano, Gino, Pisano, \& Staats, 2016). Such enhanced learning is key to effective leadership. As President John F. Kennedy stated, "Leadership and learning are indispensable to each other."

Finally, the concept of extending trust in principled leadership is rooted in the Ignatian concept of empowering others. Two-way communications are the encouragement of dialogue within our business curriculums. Moral authority and purpose are found within our spiritual commitment, exercises, and discernment. Truly, the values necessary for principled leadership are clearly found within the Jesuit business school.

\section{CONCLUSION}

We have the ability in Jesuit business education to build, with Ignatian values, a leadership vision that transforms what seems impossible into the possible, one that brings forth inquiry, innovation, authenticity, selfawareness, and empowerment. Jesuit business education includes more than teaching profit and loss; it includes "moral and justice perspectives" (Delbecq, Cavanagh, Haughey, Hendrickson, Stebbins, \& Winkler, 2010).

Jesuit business education is unique not only for its foundation on Ignatian principles but also in its ability to develop leadership characteristics through the focus on cura personalis and exercises such as magis. Cura personalis develops the humility, transparency, and trust that form the foundation of a true servant leader. Magis teaches reflection, discernment, and spirituality, thereby developing the transformational elements of leadership. It is important that these elements of Jesuit education carry over into our business school teachings. Moreover, it should be noted that solutions to environmental and sustainability issues will ultimately require global solutions. Our Jesuit business school network, which is global in reach, thus provides us a unique opportunity to develop this necessary leadership.

Finally, Jesuit business schools can clearly meet what Pope Francis calls for in Laudato Si' - to fill in the gap within sustainability leadership. Jesuit education based on Ignatian principles, as shown above, teaches both the skills and characteristics necessary for transformational leadership. If we are truly committed to social and economic justice, 
then we must include sustainability in Jesuit business education. It's a moral obligation.

As we move forward in the $21^{\text {st }}$ century, we need to reflect on what has historically made Jesuit education successful for centuries throughout the world: "the theistic worldview of Ignatius, along with the synthesis of educational principles he drew from it" (Ganss, 1989). The principles of Ignatius still apply, and they allow us to develop transformational leaders. This "Ignatian Leadership," in addition to giving us a "distinctive competence" in business education (Kim, Rivas, \& Snodgrass, 2011), puts us in a unique position to solve, through the development of transformational leaders, complex global problems like sustainability in the $21^{\text {st }}$ century.

\section{REFERENCES}

Avolio, B. J., Waldman, D. A., \& Yammarino, F. J. 1991. Leading in the 1990s: The four I's of transformational leadership. Journal of European Industrial Training, 15(4): 9-16.

Benedict XVI. 2010. Message of his holiness Pope Benedict XVI for the celebration of the World Day of Peace. Rome: Libreria Editrice Vaticana. Available at http:// w2.vatican.va/content/benedict-xvi/en/messages/peace/documents/hf_benxvi_mes_20091208_xliii-world-day-peace.html.

Bennis, W., Goleman, D., O’Toole, J., \& Biederman, P. W. 2008. Transparency: How leaders create a culture of candor. San Francisco: Jossey-Bass.

Byron, W. J. 2011. Humility, magis, and discernment: A Jesuit perspective on education for business leadership. Journal of Jesuit Business Education, 2(1): 9-20.

Callahan, R. F. 2013. Professional reflection: The alignment of Ignatian pedagogy principles with Jesuit business school education and business practices. Journal of Jesuit Business Education, 4(1): 25-35.

Center for Ethical Leadership. 2005. The leadership of sustainability: A study of characteristics and experiences of leaders bringing the "triplebottom line" to business. Available at http://www.ethicalleadership.org/ uploads/2/6/2/6/26265761/sustainability_report.pdf.

Curran, T. B. 2014. A conversation on sustainability with an Ignatian way of proceeding. Journal of Jesuit Business Education, 5(1): 5-14.

Delbecq, A. L., Cavanagh, G. F., Haughey, J., Hendrickson, A., Stebbins, M., \& Winkler, A. 2010. Higher education for business in the Jesuit tradition. Journal of Jesuit Business Education, 1(1): 119-123.

Di Stefano, G., Gino, F., Pisano, G. P., \& Staats, B. R. 2016. Making experience count: The role of reflection in individual learning. Harvard Business School NOM Unit Working Paper No. 14-093; Harvard Business School Technology \& Operations Mgt. Unit Working Paper No. 14-093; HEC Paris Research Paper No. 
SPE-2016-1181. Available at SSRN: https://ssrn.com/abstract=2414478 or http:// dx.doi.org/10.2139/ssrn.2414478.

Drucker, P. F. 2001. The essential Drucker: The best of sixty years of Peter Drucker's essential writings on management. Regan Books.

Francis. 2015. Laudato si': On care for our common home. Vatican Press. Available at http://w2.vatican.va/content/dam/francesco/pdf/encyclicals/documents/ papa-francesco_20150524_enciclica-laudato-si_en.pdf.

Ganss, G. E. 1989. St. Ignatius and Jesuit higher education. In R. E. Bonachea (Ed.), Jesuit higher education: Essays on an American tradition of excellence: 154-159. Pittsburgh: Duquesne University Press.

Garton, E. 2017. How to be an inspiring leader. Harvard Business Review, April 25. Available at https://hbr.org/2017/04/how-to-be-an-inspiring-leader.

Giles, S. 2016. The most important leadership competencies, according to leaders around the world. Harvard Business Review, March 15. Available at https:// hbr.org/2016/03/the-most-important-leadership-competencies-according-toleaders-around-the-world.

Ignatius of Loyola. 1546. Instruction for the sojourn at Trent. Rome.

Imanaka, J. L. 2016. The role of the imagination in whole person education: Creativity, empowerment, and transformation. Journal of Jesuit Business Education, 7(1): 21-38.

Kim, J., Rivas, R., \& Snodgrass, C. 2011. Where in the world is St. Ignatius Loyola? Jesuit business education for a globalized market place. Journal of Jesuit Business Education, 2(1): 65-77.

Lowney, C. 2003. Heroic leadership: Best practices from a 450-year-old company that changed the world. Loyola Press.

Martin, J. 2017. Why is climate change a moral issue? America: The Jesuit Review, March 29. Available at https://www.americamagazine.org/faith/2017/03/29/ father-james-martin-why-climate-change-moral-issue.

Mauri, A. J., Neiva de Figueiredo, J., \& Rashford, N. S. 2015. Ignatian pedagogy in the strategy classroom: Experience, reflection and action towards better managerial decisions. Journal of Jesuit Business Education, 6(1): 77-100.

Mumford, M. D., Marks, M. A., Connelly, M. S., Zaccaro, S. J., \& Reiter-Palmon, R. 2000. Development of leadership skills: Experience and timing. The Leadership Quarterly, 11(1): 87-114.

Obermiller, C., \& Atwood, A. 2014. Measuring sustainability literacy: Scale development. Journal of Jesuit Business Education, 5(1): 105-128.

Ovans, A. 2015. How emotional intelligence became a key leadership skill. Harvard Business Review, April 28. Available at https://hbr.org/2015/04/how-emotionalintelligence-became-a-key-leadership-skill.

Paul VI. 1971. Octogesima adveniens. Rome: Libreria Editrice Vaticana. Available at http://w2.vatican.va/content/paul-vi/en/apost_letters/documents/hf_p-vi_ apl_19710514_octogesima-adveniens.html.

Seidman, D. 2015. Six key principles for ethical leadership. World Economic Forum. March 16. Available at https://www.weforum.org/agenda/2015/03/sixkey-principles-for-ethical-leadership/. 
David W. Arnesen is a Professor in the Albers School of Business and Economics at Seattle University. His teaching and research interests include negotiations, leadership, and international business. He was selected as a Fulbright Specialist in 2014. 